\title{
PENGARUH PENAMBAHAN DAUN BAMBU DAN WAKTU AMALGAMASI TERHADAP PEROLEHAN EMAS
}

\author{
Rizqa Puspitarini ${ }^{1^{*}}$, Mukh Mintadi $^{2}$, Suwardiyanto $^{2}$ \\ ${ }^{1}$ Jurusan Teknik Lingkungan, Politeknik Muhammadiyah Magelang \\ Jl. Tentara Pelajar No. 12 Muntilan, Magelang, 56414. \\ ${ }^{2}$ Jurusan Kimia, Fakultas Matematika dan Ilmu Pengetahuan Alam, Universitas Jember \\ Jl. Kalimantan Kampus Tegalboto, Jember, 68121. \\ Email: rizqa@pmm.ac.id
}

\begin{abstract}
Abstrak
Daun bambu digunakan untuk pengolahan emas dalam bentuk senyawa secara amalgamasi. Variasi waktu yang digunakan untuk proses amalgamasi adalah 24 jam, 48 jam dan 72 jam. Uji-t dilakukan untuk mengetahui perbedaan antara metode amalgamasi penambahan daun bambu dan tanpa daun bambu. Hasil penelitian menunjukkan bahwa penambahan daun bambu dapat meningkatkan perolehan emas. Kadar logam emas (Au) secara amalgamasi tanpa daun bambu diperoleh sebesar 0,09 ppm, sedangkan amalgamasi dengan daun bambu memiliki kadar tertinggi sebesar 0,28 ppm. Kadar emas optimum sebesar 0,28 ppm artinya kadar yang diserap daun bambu sebesar 0,28 gram/ton. Variasi waktu proses amalgamasi berpengaruh terhadap hasil amalgamasi. Hasil terbanyak diperoleh pada proses amalgamasi selama 48 jam. Ada perbedaan yang signifikan antara kadar emas yang diperoleh dengan proses amalgamasi penambahan daun bambu dan tanpa daun bambu.
\end{abstract}

Kata kunci: amalgamasi,daun bambu, uji-t

\section{PENDAHULUAN}

Emas adalah unsur kimia dalam tabel periodik yang memiliki simbol Au (bahasa Latin: 'aurum') dan nomor atom 79. Sebuah logam transisi (trivalen dan univalen) yang bersifat lembek, mengkilap, kuning dan berat. Emas merupakan logam yang bersifat lunak dan mudah ditempa, serta berat jenisnya tergantung pada jenis dan kandungan logam lain yang berpadu dengannya. Emas dikatakan sebagai logam mulia karena secara kimia emas atau aurum $(\mathrm{Au})$ tergolong dalam kelompok logam inert $(\mathrm{Ag}, \mathrm{Au}, \mathrm{Pt})$ yaitu logam yang sulit bereaksi. Emas juga dikatakan logam mulia karena keterdapatannya di bumi sangat langka dan memiliki sifat yang spesifik (Anonim, 2016).

Metode isolasi emas yang saat ini banyak digunakan untuk keperluan eksploitasi emas skala industri adalah metode sianida dan metode amalgamasi (Rusdiarso Bambang, 2007). Namun demikian, kedua metode tersebut memiliki beberapa kelemahan. Kelemahan metode sianida adalah proses berjalan sangat lambat, dan menggunakan natrium sianida yang sangat beracun (Rusdiarso Bambang, 2007). Ekstraksi emas dengan teknik sianidasi telah lama digunakan secara komersial namun saat ini proses sianidasi menjadi masalah yang sangat berat karena limbah proses yang dihasilkan menimbulkan dampak lingkungan sangat serius sebagai akibat dari senyawa sianida yang sangat berbahaya (Suratman, 2006).

Salah satu bentuk pengembangan proses amalgamasi di Indonesia adalah penambahan sejumlah daun ke dalam proses amalgamasi sebagai bahan aditif. Menurut para penambang tradisional, penambahan daun tersebut diyakini dapat memperbaiki tingkat perolehan (recovery) logam emas dan perak ketika berlangsungnya proses amalgamasi (Agustinus dan Yuniati, 2007).

Daun bambu banyak terkandung senyawa hidrosianida dan asam benzoat (Anonim, 2016). Efektifitas ekstraksi emas dapat diperbaiki dengan penambahan daun bambu. Penambahan daun bambu ini diharapkan mampu memperbaiki efektivitas ekstraksi emas.

\section{METODOLOGI \\ Alat dan Bahan}

Alat yang digunakan dalam penelitian ini adalah beaker glass $600 \mathrm{~mL}$, erlenmeyer 250 $\mathrm{mL}$, kertas saring, corong pisah, pipet tetes, pipet volume, ball pipet, alumunium foil, $\mathrm{pH}$ meter, pengaduk, stirrer, ayakan $0,15 \mathrm{~mm}( \pm$ 100 mesh), lumpang besi, labu ukur $50 \mathrm{~mL}$, labu ukur $100 \mathrm{~mL}$, gelas ukur $50 \mathrm{~mL}$, shaker, 
neraca analitik dan instrumen AAS (Buck Scientific 205 AAS).

Bahan-bahan yang dibutuhkan adalah batuan emas dari tambang emas Banyuwangi, larutan standar emas $(\mathrm{Au}) 1000 \mathrm{ppm}$ dari Baker Instra Analyzed, air raksa (Hg) khusus emas 99,99\% dari PT. Taman Eden Bali, daun bambu tua dari spesies Gigantochloa hasskarliana (Kurz) ex Heyne, aquades, asam nitrat pekat $\left(\mathrm{HNO}_{3}\right) 65 \%$ dari Merck dan asam klorida pekat $(\mathrm{HCl}) 36,5-38 \%$ dari Mallinckrodt.

\section{Prosedur Kerja}

\section{Pembuatan Larutan Standar Emas}

Larutan standar emas 1000 ppm diambil $1 \mathrm{~mL}$, dimasukkan ke dalam labu ukur $100 \mathrm{~mL}$ dan diencerkan dengan aquades sampai tanda batas. Larutan standar emas $10 \mathrm{ppm}$ diambil $0 \mathrm{~mL} ; 1 \mathrm{~mL}, 2 \mathrm{~mL} ; 3 \mathrm{~mL} ; 4 \mathrm{~mL}$; $5 \mathrm{~mL}$ dan dimasukkan ke dalam labu ukur $50 \mathrm{~mL}$ serta diencerkan dengan aquades sampai tanda batas, sehingga diperoleh larutan standar emas 0 ppm ; 0,2 ppm ; 0,4 ppm ; 0,6 ppm ; 0,8 ppm dan $1 \mathrm{ppm}$.

\section{Pembuatan Kurva Kalibrasi Larutan Standar Emas}

Larutan standar emas 0 ppm ; 0,2 ppm ; 0,4 ppm ; 0,6 ppm ; 0,8 ppm dan 1 ppm diukur absorbansi menggunakan spektrometri serapan atom serta dibuat kurva kalibrasi dengan sumbu $\mathrm{x}$ sebagai konsentrasi larutan standar dan sumbu y sebagai absorbansi.

\section{Pengolahan Sampel}

Batuan emas dipecah-pecah sampai berukuran kecil, dihaluskan dengan menggunakan lumpang besi, diayak menggunakan ayakan $0,15 \mathrm{~mm}( \pm 100 \mathrm{mesh})$, dihomogenkan dan ditimbang sebanyak 50 gram untuk masing-masing sampel analisis.

\section{Analisis Kadar Emas (Au) dalam Batuan}

Batuan emas yang telah dihomogenkan sebanyak 50 gram dimasukkan ke dalam beaker glass $600 \mathrm{~mL}$, ditambahkan $25 \mathrm{~mL}$ larutan aqua regia dan $150 \mathrm{~mL}$ aquades, disaring, diambil sebanyak $10 \mathrm{~mL}$, diencerkan ke dalam labu ukur $100 \mathrm{~mL}$ dan diukur kadar emas menggunakan spektrometri serapan atom

\section{Analisis Kadar Emas Secara Amalgamasi Tanpa Daun Bambu}

Batuan emas yang telah dihomogenkan sebanyak 50 gram dimasukkan ke dalam erlenmeyer $250 \mathrm{~mL}$, ditambahkan 150 $\mathrm{mL}$ aquades, 25 gram air raksa, diukur $\mathrm{pH}$ sampai menunjukkan $\mathrm{pH}$ 9-10, dishaker menggunakan kecepatan putar 100 rpm selama 24 jam. Hasil amalgamasi dituang ke dalam piring, dialiri air kran dengan menggunakan botol semprot, endapan ditampung ke dalam baki sehingga air raksa dan endapan terpisah. Sisa endapan dilarutkan ke dalam $25 \mathrm{~mL}$ larutan aqua regia, disaring, diambil sebanyak $10 \mathrm{~mL}$, diencerkan ke dalam labu ukur $100 \mathrm{~mL}$ dan diukur kadar emas menggunakan spektrometri serapan atom.

\section{Analisis Kadar Emas Secara Amalgamasi dengan Daun Bambu}

Batuan emas yang telah dihomogenkan sebanyak 50 gram dimasukkan ke dalam erlenmeyer $250 \mathrm{~mL}$, ditambahkan $150 \mathrm{~mL}$ aquades, 25 gram air raksa, 1,8 gram daun bambu, diukur $\mathrm{pH}$ sampai menunjukkan $\mathrm{pH}$ 910, dishaker menggunakan kecepatan putar 100 rpm selama 24 jam. Hasil amalgamasi dituang ke dalam piring, dialiri air kran dengan menggunakan botol semprot, endapan ditampung ke dalam baki sehingga air raksa dan endapan terpisah. Sisa endapan dilarutkan ke dalam $25 \mathrm{~mL}$ larutan aqua regia, disaring, diambil sebanyak $10 \mathrm{~mL}$, diencerkan ke dalam labu ukur $100 \mathrm{~mL}$ dan diukur kadar emas menggunakan spektrometri serapan atom.

\section{Analisis Kadar Emas Secara Amalgamasi Menggunakan Variasi Waktu}

Batuan emas yang telah dihomogenkan sebanyak 50 gram dimasukkan ke dalam erlenmeyer $250 \mathrm{~mL}$, ditambahkan $150 \mathrm{~mL}$ aquades, 25 gram air raksa, 1,8 gram daun bambu, diukur $\mathrm{pH}$ sampai menunjukkan $\mathrm{pH}$ 910, dishaker menggunakan kecepatan putar 100 rpm selama 24 jam, 48 jam dan 72 jam. Hasil amalgamasi dituang ke dalam piring, dialiri air kran dengan menggunakan botol semprot, endapan ditampung ke dalam baki sehingga air raksa dan endapan terpisah. Sisa endapan dilarutkan ke dalam $25 \mathrm{~mL}$ larutan aqua regia, disaring, diambil sebanyak $10 \mathrm{~mL}$, diencerkan ke dalam labu ukur $100 \mathrm{~mL}$ dan diukur kadar emas menggunakan spektrometri serapan atom.

\section{Analisis Data \\ Uji-t}


Uji- $t$ dapat diperoleh dengan menghitung nilai $\mathrm{x}$ untuk respon metode pertama dan nilai y untuk respon metode kedua. Nilai t-eksperimen diperoleh melalui persamaan berikut :

$$
\begin{aligned}
\mathrm{S}^{2} & \left.=\left\{\mathrm{n}_{1}-1\right) \mathrm{S}_{1}^{2}+\left(\mathrm{n}_{2}-1\right) \mathrm{S}_{2}^{2}\right\} \\
\mathrm{t}_{\mathrm{eks}} & =\frac{\left(\mathrm{n}_{1}+\mathrm{n}_{2}-2\right)}{s \sqrt{\frac{1}{n_{1}}+\frac{1}{n 2}}}
\end{aligned}
$$

pertama

$$
\text { dimana } \overline{x_{1}} \quad=\text { mean data metode }
$$

$\overline{x_{2}} \quad=$ mean data metode kedua

$\mathrm{S}_{1}=$ standar deviasi rata-rata metode pertama,

$\mathrm{S}_{2}=$ standar deviasi rata-rata metode kedua

$$
\begin{aligned}
& \mathrm{S}=\text { standar deviasi total } \\
& \mathrm{n}_{1}=\text { jumlah pengulangan }
\end{aligned}
$$

percobaan metode pertama

$$
\mathrm{n}_{2}=\text { jumlah pengulangan }
$$

percobaan metode kedua

(Miller, J.C, dan Miller, J.N, 1991)

Jika nilai t-eksperimen lebih kecil dibandingkan dengan nilai t-tabel, maka secara statistik kedua metode tersebut tidak mempunyai perbedaan signifikan pada selang kepercayaan $95 \%(\alpha=0,05)$ (Sudjana, 1996). Analisis data untuk dua metode dibandingkan dengan menguji sampel yang berbeda menggunakan uji statistik salah satunya uji-t, dimana untuk menghitung nilaidari hasil eksperimen didapatkan melalui persamaan 1 dan 2

\section{HASIL DAN PEMBAHASAN \\ Pengolahan dan Analisis Kadar Emas}

Persiapan sampel emas dapat dilakukan dengan menghaluskan batuan emas dengan menggunakan lumpang besi dan diayak menggunakan ayakan $0,15 \mathrm{~mm}$ ( $\pm 100 \mathrm{mesh})$. Ayakan 100 mesh artinya 1 inchi ada 100 lubang. Sampel yang telah diayak kemudian dihomogenkan dan ditimbang. Tujuan dihomogenkan adalah untuk memperoleh ukuran sampel yang seragam.

Analisis kadar emas dapat dilakukan dengan memasukkan 50 gram batuan yang telah dihomogenkan ke dalam erlenmeyer $250 \mathrm{~mL}$, ditambahkan $150 \mathrm{~mL}$ aquades, 25 gram air raksa dan 1,8 gram daun bambu. Aquades dan air raksa berfungsi untuk melarutkan batuan emas saat proses amalgamasi. Emas dapat terlarut dengan air raksa, sehingga raksa dipakai untuk mengikat emas dalam proses amalgamasi. Daun bambu berfungsi sebagai bahan aditif. Tahap amalgamasi ini $\mathrm{pH}$ diukur sampai menunjukkan pH 9-10. pH terlalu kecil maka akan cenderung akan terbentuk perunggu (perunggu lebih stabil dibandingkan dengan amalgam emas pada $\mathrm{pH}<9$ ), jika $\mathrm{pH}>10$ maka laju pembentukan amalgam menjadi lebih lambat (Widodo, 2008). Tahap amalgamasi ini dishaker selama 24 jam, 48 jam dan 72 jam dengan kecepatan putar sekitar 100 rpm dimaksudkan agar terjadi proses pengadukan. Proses pengadukan akan meningkatkan pengikatan emas oleh air raksa membentuk amalgam. Hasil amalgamasi dituang ke dalam piring, dialiri air kran dengan botol semprot. Sisa endapan ditampung ke dalam baki sehingga air raksa dan endapan terpisah. Sisa endapan ini dilarutkan ke dalam $25 \mathrm{~mL}$ larutan aqua regia. Aqua regia mampu melarutkan emas. Aqua regia dibuat dengan menggunakan perbandingan 3: 1 antara asam klorida dan asam nitrat. Hasil pelarutan sisa endapan dengan aqua regia ini disaring dan diambil $1 \mathrm{~mL}$ serta diencerkan ke dalam labu ukur $100 \mathrm{~mL}$. Pengenceran meruapakan mencampur larutan pekat (konsentrasi tinggi) dengan cara menambahkan pelarut agar diperoleh volume akhir yang lebih besar. Kadar emas diukur dengan menggunakan spektrometri serapan atom pada panjang gelombang $242,8 \mathrm{~nm}$.

\section{Kurva Kalibrasi Emas}

Pembuatan larutan standar emas $(\mathrm{Au})$ dapat dilakukan dengan mengambil $1 \mathrm{~mL}$ larutan standar emas (Au) 1000 ppm, dimasukkan ke dalam labu ukur $100 \mathrm{~mL}$ dan diencerkan dengan aquades sampai tanda batas. Larutan standar emas $10 \mathrm{ppm}$ diambil $0 \mathrm{~mL} ; 1$ $\mathrm{mL}, 2 \mathrm{~mL} ; 3 \mathrm{~mL} ; 4 \mathrm{~mL}$; $5 \mathrm{~mL}$ dan dimasukkan ke dalam labu ukur $50 \mathrm{~mL}$ serta diencerkan dengan aquades sampai tanda batas, sehingga diperoleh larutan standar emas $0 \mathrm{ppm} ; 0,2 \mathrm{ppm}$ ; 0,4 ppm ; 0,6 ppm ; 0,8 ppm dan 1 ppm.

Kurva kalibrasi emas diperoleh dengan memplotkan konsentrasi larutan standar emas terhadap absorbansi. Penelitian ini menggunakan larutan standar emas 0 ppm ; 0,2 ppm ; 0,4 ppm ; 0,6 ppm ; 0,8 ppm dan 1 ppm. Larutan standar emas diukur dengan menggunakan spektrometri serapan atom pada panjang gelombang 242,8 nm. Pengukuran 
kadar emas $(\mathrm{Au})$ dalam batuan dimulai dengan pengukuran absorbansi larutan standar emas. Kurva kalibrasi emas disajikan pada gambar 1 di bawah ini :

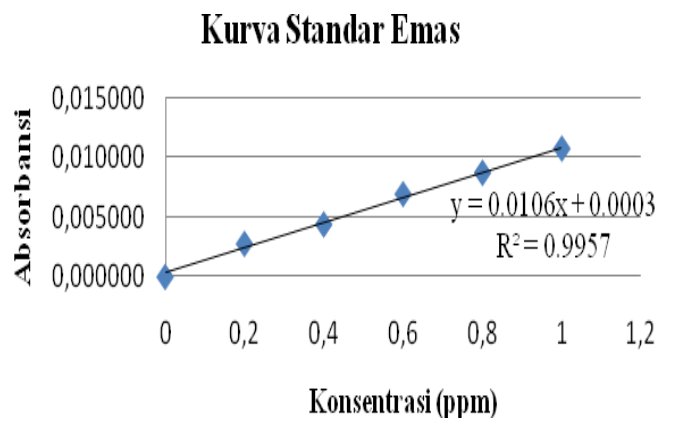

Gambar 1. Kurva Kalibrasi Emas

Berdasarkan gambar 4.1 diperoleh persamaan regresi linear yang merupakan hubungan antara absorbansi (y) dengan konsentrasi (x) larutan standar sebagai berikut : $y=0,0106 x+0,0003$ dengan harga $R^{2}$ sebesar 0,9957 artinya nilai variabel dependen (absorbansi) yang dapat dijelaskan oleh variabel independen (konsentrasi) sebesar 99,57\%, sedangkan $0,43 \%$ sisanya dijelaskan oleh kesalahan atau pengaruh variabel lain. Kadar emas $(\mathrm{Au})$ dalam sampel dilakukan pengukuran absorbansi dari larutan sampel. Kadar emas dalam sampel diperoleh dengan cara mensubstitusikan nilai absorbansi larutan sampel pada persamaan $y=0,0106 x+0,0003$.

\section{Kadar Emas (Au) dalam Batuan}

Emas umumnya ditemukan dalam bentuk logam yang terdapat dalam batuan. Kelimpahan relatif emas didalam kerak bumi diperkirakan sebesar 0,004 g/ton (Rusdiarso Bambang, 2007). Kadar emas (Au) dalam batuan yang diperoleh sebesar $0,44 \mathrm{ppm}$ artinya kadar emas (Au) dalam batuan sebesar 0,44 gram/ton. Batuan tersebut mengandung emas lebih besar dari rata-rata emas yang ada di alam. Kadar emas (Au) yang diperoleh dalam sampel ini sebesar 0,44 gram/ton. Kadar emas yang diperoleh tiap daerah pertambangan akan berbeda tergantung dari kondisi bijih dan keadaan fisik pertambangan. Kadar emas (Au) dalam batuan akan dijadikan sebagai referensi pada pengukuran kadar emas berikutnya.

\section{Efek Penambahan Daun Bambu Terhadap Amalgamasi Emas}

Salah satu bentuk pengembangan proses amalgamasi emas adalah penambahan sejumlah daun bambu. Penambahan daun bambu ini diyakini dapat memperbaiki tingkat perolehan emas ketika proses amalgamasi berlangsung. Pengukuran kadar emas yang ada di raksa lebih rumit bila dibandingkan dengan menggunakan sisa endapan dari batuan emas. Raksa mampu melarutkan logam lain seperti emas dan perak membentuk logam paduan (amalgam). Emas dan perak adalah logam yang dapat terlarut dengan merkuri, sehingga merkuri dipakai untuk mengikat emas dalam proses pengolahan bijih secara amalgamasi. Proses pemisahan emas yang ada di raksa dapat dilakukan dengan memisahkan emas dari raksa terlebih dahulu, dilanjutkan dengan proses pemisahan emas dari campuran logam lain (perak dan tembaga). Pemisahan emas yang ada di raksa dapat dilakukan dengan menggunakan sistem retort. Sistem retort ini menghasilkan uap raksa yang berbahaya bagi kesehatan dan membutuhkan waktu yang lama.

\section{Kadar Emasyang Diekstraksi dengan Penambahan Daun Bambu dan Tanpa Daun Bambu}

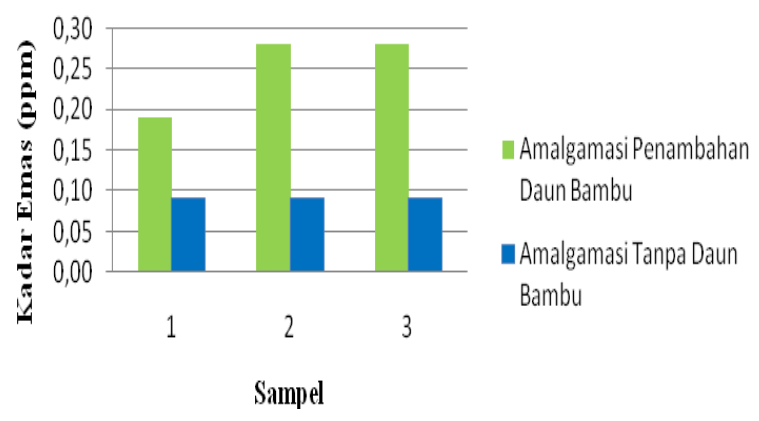

\section{Gambar 2. Efek Penambahan Daun Bambu Terhadap Hasil Amalgamasi}

Gambar 2 terlihat bahwa dengan penambahan daun bambu dapat mempengaruhi hasil amalgamasi dari batuan. Kadar logam emas $(\mathrm{Au})$ secara amalgamasi tanpa daun bambu diperoleh sebesar 0,09 ppm, sedangkan amalgamasi pakai daun bambu memiliki kadar tertinggi sebesar 0,28 ppm. Kadar emas optimum sebesar 0,28 ppm artinya kadar yang diserap daun bambu sebesar 0,28 gram/ton. Berdasarkan kondisi tersebut maka ada perbedaan yang signifikan antara kadar emas yang diperoleh penambahan daun bambu dan tanpa daun bambu.

Daun bambu ini berfungsi sebagai bahan aditif dimana terjadi interaksi dengan logam emas saat proses amalgamasi berlangsung, sehingga amalgam bisa menyerap 
daun bambu. Menurut (Gardea-Torresdey, et al, 1998) sejak lama telah diketahui bahwa tumbuhan memiliki kemampuan untuk mengambil emas dari tanah dan mengakumulasikannya dalam jaringan secara cepat, baik secara aktif melalui metabolisme tumbuhan atau secara pasif melalui gugus fungsional dalam jaringan tumbuhan. Kemampuan ini dapat dimanfaatkan untuk memperoleh kembali ion emas(III) dari larutannya.

Daun bambu mengandung asam sianida dan asam benzoat (Anonim, 2010). Asam sianida yang terkandung dalam daun bambu akan bereaksi dengan batuan emas membentuk anion disiano emas (I). Reaksi yang terjadi antara asam sianida dan emas sebagai berikut : $4 \mathrm{Au}+8 \mathrm{CN}^{-}+\mathrm{O}_{2}+2 \mathrm{H}_{2} \mathrm{O} \rightarrow 4 \mathrm{Au}(\mathrm{CN})_{2}{ }^{-}+$ $4 \mathrm{OH}^{-}$

Anion disiano emas (I) akan mengalami reaksi reduksi menjadi logam emas dan ion sianida. Berdasarkan kondisi tersebut, daun bambu mampu mengekstrak emas dari batuan.

\section{Efek Variasi Waktu Terhadap Hasil Amalgamasi Emas \\ Berdasarkan gambar 3 terlihat bahwa variasi waktu dapat mempengaruhi hasil amalgamasi. Hal ini terlihat pada waktu amalgamasi variasi waktu 48 Jam. Waktu amalgamasi 48 jam memiliki kadar emas yang paling optimum bila dibandingkan dengan kadar emas waktu amalgamasi 24 jam dan 72 jam.}

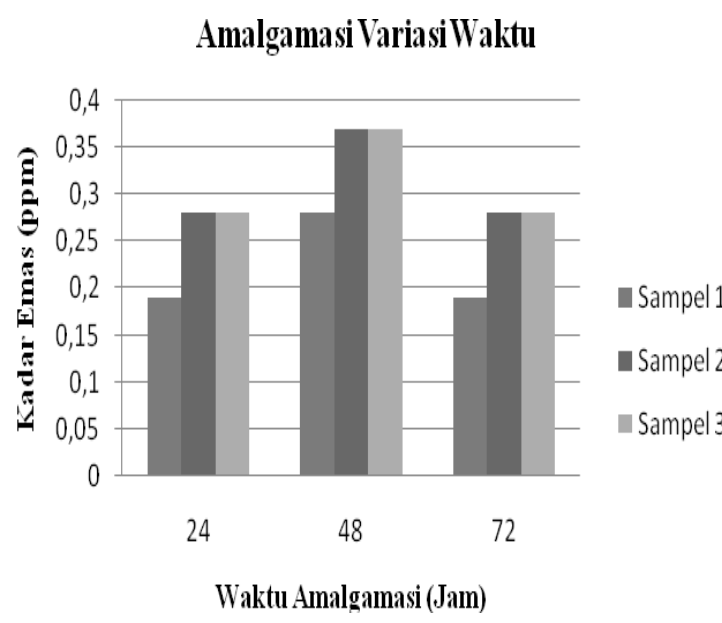

\section{Gambar 3. Efek Variasi Waktu dalam Proses Amalgamasi}

Waktu amalgamasi yang lebih lama cenderung memberikan tingkat perolehan emas rendah. Hal ini disebabkan karena dengan memperpanjang waktu amalgamasi kemungkinan akan terbentuknya kristal dari raksa sehingga proses penyerapan emas menjadi tidak efektif. Waktu amalgamasi yang lama ini diimbangi dengan perubahan variabel lainnya maka perolehan emas dapat dinaikkan kembali. Keberhasilan analisis dan interpretasi pengaruh variabel-variabel terhadap perolehan emas bergantung pada kondisi bijih (Ardiwilaga dan Sumarnadi, 1994).

\section{KESIMPULAN}

Berdasarkan hasil penelitian maka dapat diambil beberapa kesimpulan sebagai berikut :

1. Penambahan daun bambu dapat meningkatkan tingkat perolehan emas. Hasil perolehan emas tertinggi dengan penambahan daun bambu sebesar 0,28 ppm.

2. Variasi waktu proses amalgamasi berpengaruh terhadap hasil amalgamasi. Hasil terbanyak diperoleh pada proses amalgamasi selama 48 jam.

\section{DAFTAR PUSTAKA}

Agustinus, Eko dan Yuniati, Mulia Dewi., 2007, Peranan Daun Babadotan (Ageratum Conizpides), Nampong Nampong (Eupatorium Molifolium) dan Asipatihe-ur (Lantana Camara) sebagai Bahan Aditif dalam Amalgamasi Bijih Emas pada Pertambangan Rakyat,Bandung, Pusat Penelitian Geoteknologi LIPI

Anonim,2016, Bamboo Medicinal Properties and Benefit. http://www.home-remediesguide.com/herbs/bamboo.htm. Diakses : 20 Oktober 2016

Anonim.,2016,Emas.http://id.wikipedia.org/wik i/Emas. Diakses : 20 Oktober 2016

Ardiwilaga, Suryadi dan Sumarnadi, Eko Tri., 1994, Pengaruh Waktu Amalgamasi dan Penambahan Natrium Sianida, Kapur serta Kalium Nitrat terhadap Ting- kat Perolehan Emas dan Kehilangan Air Raksa dalam Amalgamasi Bijih dari Ulu Ketenong. Bengkulu : Puslitbang Geoteknologi

Gardea-Torresdey,J.L, K.J. Tiemann, J.H.Gonzalez, O. Rodriguez, and G. Gamez., 1998, Phytofiltration of Hazardous Cadmium, Chromium, Lead and Zinc Ions Biomass of 
Medicago Satuva (Alfafa), J. Hazard. Mater., 57, pp. 29-39

Miller, J.C dan Miller, J.N ., 1991, Statistika untuk Kimia Analitik. Bandung : Insti-

tut Teknologi Bandung

Rusdiarso, Bambang., 2007, Studi Ekstraksi Pelarut Emas (III) dalam Larutan Konse-entrat Tembaga PT Freeport dengan 8Metylxantin. Yogyakarta : Kimia FMIPA UGM

Suratman., 2006, Pelindian Bijih Emas dengan Larutan Amonia Tiosulfat. http:// tekmira.esdm.go.id/Hasillitbang/?p=244.

Diakses : 10 Oktober 2016 